\title{
WHAT WOULD HAPPEN IF PUBLIC HEALTH NUTRITIONISTS REALLY CARED MORE ABOUT HUNGER AND MALNUTRITION FROM A RIGHT TO NUTRITION PERSPECTIVE?
}

\author{
Claudio Schuftan
}

The current malnutrition problem around the world is not its double burden, but it is multiple burdens. Thus the question is: by narrowly focusing on the greater appeal of reducing hunger, what do we risk?

In public health nutrition work, some colleagues focus on hunger, some do not; some are into magic bullets, some not. By narrowly focusing on reducing hunger, a number of colleagues risk solely or chiefly focusing on increasing dietary energy supply or consumption. But, beware, this does not adequately address the more complex challenges that fulfilling the right to nutrition brings about. To live up to these challenges cannot be made to mean following a number of magic-bullet interventions to achieve them. Why? Among other things, (a) because the list of selected interventions risks being reduced to a simplistic shopping list from which one can choose according to ad-hoc preferences and experiences from elsewhere, with no proof they will work; and (b) more basically, because we live in a world dominated by markets, where resources flow towards power instead of need. The way I always explain this to my students and audiences is like this: You all know the "give me a fish and you feed me for a day" proverb, no? Well, what the Chinese wisdom failed to add is that teaching the hungry to fish does not help if the pond, lake, or river is privately owned and the hungry are not allowed to fish there...

So, how can public health nutrition colleagues so inclined assure that the human rights principles and standards are woven into the right to nutrition? Here is a call to start discussions around how we have been blindsided by a focus on hunger and nutrition rather than the realization of the right to nutrition.

For any change to happen, all of us need to start a truly transformative process in order to de-block some of the lock-ins that obstruct change in our system and that have been allowed to grow over the past 50 years. As a former UN Rapporteur on the Right to Food once said: "Perhaps the most significant lock-in is political in nature" (de Schutter, 2014). Furthermore, take the high level UN panels specially set up to deal with the topic: they have separated the political issues from the technical ones in an effort to build a purported 'common understanding' or consensus --but where is this leading us to?

Those among us unquestioningly following the orthodoxy of the neoliberal paradigm have some of the responsibility to bare: 'Laborious, duplicative, weak, grossly insufficient, poorly targeted, fragmented, dysfunctional'. These are all critical judgments we hear about the 'global architecture' designed to address under-nutrition the world over. Some architecture! (Uauy, 2012) From this point of view, is our profession, divided as it is on these issues, in many cases, suffering from irrelevance and incompetence and also from ignorance, obsolescence, complacency, sometimes even amenable to be bought? 
This brings us squarely into the main question of this article as stated in its title. From the human rights perspective, the huge challenge I am talking about in the long term is converting passive food consumers into active food citizens, i.e., active claim holders demanding their right to nutrition.

While we do recognize the hugely valuable contribution that technology and innovation can make to nutritional outcomes, a growing number of us feel that, from one important perspective, there is a need to redress the balance between what a technological and an ecological focus can achieve so that traditional farming and food production practices that have evolved over millennia greatly contributing to food security and nutrition are given equal or greater attention and are afforded the recognition, protection, and support they deserve. Add to this the need for food chains to be shortened and scrutinized for undue profiteering by intermediaries. Yes, consumers mobilized as food citizens/claim holders are key here. Moving away from the individualistic ethos promoted by the industrial food system.

The good news is that the growing movement is from passive food consumers to active food citizens that develop food democracies where food must be valued as a vital resource, as a human right, as a cultural determinant and as a common good. (Vivero-Pol, 2017)

This said, it is key to start identifying and developing sustainable nutrition strategies that start from the understanding of the local constraints and opportunities food citizens are facing, i.e., start from the individuals suffering from malnutrition and, therefore, the households and communities they live-in. Together with them, public health nutritionists going to the field must analyze the causes of malnutrition they face. Only this will lead colleagues to understand the food systems that food producers and consumers interact with and the decision-making power they have--if any. Experience shows that malnutrition results from imposed food systems that negatively impinge on people's livelihoods. (Via Campesina, 2007). Until now, the nutrition world (including some of the top experts) has emphasized biomedical approaches to complement nutrient deficiencies rather than looking at local-specific causes--quite a few of which relate to human rights determinants of malnutrition.

The currently competing food systems are co-existing in a highly unfair manner, as industrial food systems are outcompeting and choking more environmentally sustainable food systems. How long can the primary corporate rule on what is available for consumers to choose to eat be accepted and condoned?

Changing this means mobilizing food citizens more actively to work towards some degree of regulation over the market. Industry is 'educating' the general population on how to eat fast foods and ultraprocessed foods while too many colleagues still go on blaming individuals for their 'wrong choices and behavior', i.e., falling for the clever food industry ploy of "blaming the victim" for making 'unhealthy choices'.

Poor city dwellers, not only peasants suffer from malnutrition. The former are often unemployed, underpaid or in the grey subsistence market, the latter may not eat what they produce, have no access to markets and/or get underpaid as day laborers. Both groups buy ultra-processed foods that, in reality should be called 'edible products' rather than "food".

Other high risk groups include (a) transnational corporations' plantation workers who produce for the global market; (b) peasants under threat due to land grabbing; (c) indigenous people, some of whom are 
farmers (that are further being repressed when they struggle for their ancestral lands); (d) pastoralists who have special nutrition problems (little access to vegetables and a shrinking of the commons); and (e) fisherfolks suffering from lake and ocean grabbing. All these groups must fight for living wages, for access to health, for their safety, for maternity benefits and fight against the privatization of the commons and the pervasive consumer misinformation provided by Big Food. They must go from having their voices heard to exerting de-facto influence. Moreover, keeping nutrition policies separate from food policies too often leads to the former becoming very technical and too often product- and/or nutrient-based and oriented. Nutrition and food policies simply must be addressed together. (Valente, 2015)

Between the Davos World Economic Forum and La Via Campesina at the extremes, both trying to address the food and nutrition security problem, there is a complex mix of intergovernmental organizations within and beyond the UN system, including FAO, WHO, WFP, UNICEF, the World Trade Organization and the World Bank. Among these agencies, a whole range of organizational approaches have been developed, but many of these carry along what is a hidden corporate program. Among the most prominent is the SUN (Scaling Up Nutrition) Initiative, a 'multistakeholder platform' heavily criticized for its built-in conflicts of interest through active corporate sector participation. Typical for worst offenders, the SUN Initiative has no accountability to any UN or government body or process.

New UN lingo reflects the hidden industry agenda. One example is 'nutrition-sensitive social protection'. Think about it. What is this really? Why was it necessary for pertinent UN agencies to come up with a new construct/new language with a fancy name? The best many of us can figure is that, influenced as they are, UN agencies wanted to water-down the concept of social determinants of nutrition which are as well defined as are the social determinants of health. The need of communities is for the social and political determinants of malnutrition (not nutrition-'sensitive' issues) to be addressed to protect them from food insecurity, hunger and malnutrition. Another such term favored by the UN agencies is 'nonstate actors' that lumps together private with public actors as if they were equals --disregarding who really is acting in the public interest and who on the interest of stockholders.

Bottom line: plans to address hunger and malnutrition cannot get stuck in 'could', 'should', and 'may'. The politics of 'could', 'should', and 'may' has to end. Appropriate plans must strengthen the peoples' right to self-determination in the economic domain. This must be seen as an indispensible complement and not as a substitute for the intrinsically human rights-centered goal of eliminating malnutrition with its multiple burdens. Grassroots human rights organizations must be supported. Concepts such as that of 'food sovereignty' must be reclaimed, that is, the notion that involves breaking up with fundamental aspects of the heterodoxy of global capitalism that wants to treat food as a sheer commodity, in practice ignoring nations' needs for national food security. Nutrition is a fundamental part of food sovereignty in that it is the affected themselves who actively participate in setting and implementing policies that address nutrition issues beyond food security. (RTFN Watch, 2015).

\section{Acknowledgement}

The author additionally acknowledges that his piece has been influenced by the writings of Maria Duenias, Biraj Patnaik, Florence Egal, Jennifer Dias, Simone Lovera, Miryam Gorban, C. Haeberli, David Legge, C. Schmidt, E. Arenas, and John Hoddinott. (The reason for doing so is to give credit where it is due; their ideas typically did not come from standard places one can reference). 


\section{References}

Aksnes, B. 2016. In review of George Kent's book Caring About Hunger. Sparsnäs, Sweden: Irene Publishing.

De Schutter, O. 2014. Final Report to U Human Rights Council. http://www.srfood.org/en/final-reportto-un-human-rights-council. Accessed Oct 16, 2017.

Right to Food and Nutrition Watch. 2015. People's Nutrition is not a Business, Issue 07, 2015. www.rtfnwatch.org. Accessed Oct 16, 2017.

Uauy, R. 2012. A Decision Pathway for Nutrition Intervention and Delivery Strategies: The Next Step to Improved Nutrition for Young Children, Discussion Draft 0205085 of 5, Institute of Medicine, Washington, DC.

Valente, F. 2015. Personal communication.

Via Campesina. 2007. DECLARATION OF NYÉLÉNI - Via Campesina accessed Oct 16, 2017

Vivero-Pol, J.L. 2017. The idea of food as commons or commodity in academia. A systematic review of English scholarly texts. 53:182-201.

http://www.sciencedirect.com/science/article/pii/S0743016716305551. Accessed Oct 16, 2017. 